\title{
Anal Cancer pTX TNM Finding v6 and v7
}

National Cancer Institute

\section{Source}

National Cancer Institute. Anal Cancer pTX TNM Finding v6 and v7. NCI Thesaurus. Code C67536.

Anal cancer in which the primary tumor cannot be assessed. (from AJCC 6th and 7th Eds.) 